\title{
Analisis Respon Dinamik Tanah Berpotensi Likuifaksi \\ Pada Underpass Yogyakarta International Airport (YIA)
}

\section{Muhamad Agung Rahman', Teuku Faisal Fathani' ${ }^{2}$ Ahmad Rifa'i ${ }^{3}$}

Mahasiswa Program Magister Teknik Pengelolaan Bencana Alam ${ }^{1}$, Teknik Sipil dan Lingkungan, Fakultas Teknik, Universitas Gadjah Mada, Yogyakarta ${ }^{1}$ Departemen Teknik Sipil dan Lingkungan,

Fakultas Teknik, Universitas Gadjah Mada, Yogyakarta ${ }^{2,3}$

Email : muhamad.a.r@mail.ugm.ac.id ${ }^{1,}$ tfathani@ugm.ac.id ${ }^{2}$ ahmad.rifai@ugm.ac.id ${ }^{3}$ DOI: http://dx.doi.org/10.31869/rtj.v4i1.1916

\begin{abstract}
Abstrak: Underpass Yogyakarta International Airport (YIA) terletak di pesisir pantai selatan jawa dekat dengan pertemuan lempeng tektonik. Kondisi geologi di lokasi Underpass YIA termasuk formasi geologi endapan alluvial, dimana sepanjang underpass ditemukan lapisan tanah berupa lempung pasiran dan pasir. Aktivitas seismik serta kondisi geologi dan geoteknik menyebabkan wilayah Underpass YIA rentan terhadap gempa bumi berpotensi likuifaksi. Penelitian ini bertujuan untuk menganalisis respon dinamik tiap lapisan tanah berpotensi likuifaksi dengan ragam spektrum Multi Degree of Freedom serta memodelkan lapisan tanah berupa shear building. Evaluasi bawah permukaan didasarkan pada data pengeboran dan $N$-SPT serta data tanah pada 5 titik di sepanjang Underpass YIA. Nilai percepatan batuan dasar ditentukan berdasarkan peta gempa SNI 1726-2012. Piranti lunak MATLAB digunakan sebagai alat bantu dalam perhitungan analisis perilaku dinamik. Hasil analisis menunjukkan bahwa nilai simpangan tiap lapisan tanah semakin mendekati permukaan cenderung semakin besar karena nilai kekakuan tanah semakin mengecil. Kekakuan tanah yang semakin kecil menghasilkan nilai frekuensi sudut semakin kecil dan periode getar semakin besar mendekati permukaan tanah. Hasil analisis menunjukkan adanya potensi likuifaksi pada kedalaman 4$6 \mathrm{~m}$ dari permukaan tanah jika terjadi gempa bumi dengan nilai percepatan muka tanah maksimum $\left(a_{\max }\right)$ lebih besar dari $0,44 \mathrm{~g}$.
\end{abstract}

Kata Kunci : Likuifaksi, kekakuan tanah, percepatan batuan dasar, shear building, MATLAB.

\section{PENDAHULUAN}

Pembangunan bandar udara baru di Daerah Istimewa Yogyakarta (DIY) yaitu Yogyakarta International Airport (YIA) telah berdampak terputusnya Jalan Jalur Lintas Selatan (JJLS) Jawa yang menghubungkan DIY dengan Provinsi Jawa Tengah (Kabupaten Purworejo). Untuk memecahkan permasalahan tersebut, Pemerintah melaksanakan pembangunan terowongan bawah tanah (underpass) sepanjang $\pm 1,3$ kilometer yang dinamakan Underpass Yogyakarta International Airport (YIA).

Underpass YIA terletak di daerah pesisir pantai selatan jawa yang dekat dengan pertemuan lempeng tektonik yaitu Lempeng Eurasia dan Lempeng Indo-Australia, seperti yang ditunjukkan pada Gambar 1. Pergerakan antar lempeng tersebut menciptakan jalur subduksi (penujaman) dan jalur tubrukan aktif, sehingga jarak lokasi Underpass YIA yang relatif dekat dengan pertemuan lempeng tektonik di selatan Pulau Jawa memiliki potensi bahaya terjadinya gempa bumi.
Kondisi geologi regional di lokasi Underpass YIA berdasarkan Peta Geologi lembar Yogyakarta Jawa tahun 1977, termasuk ke dalam formasi geologi endapan alluvial (Gambar 2). Berdasarkan hasil penyelidikan lapangan dan uji laboratorium di sepanjang underpass diketahui lapisan tanah di sebagian besar lokasi di bagian permukaan adalah lapisan lempung lanauan atau lempung pasiran (tanah kohesif) dengan tebal bervariasi antara 0,5 $\mathrm{m}$ hingga $3 \mathrm{~m}$ kecuali di ujung sisi timur. Di bawah lapisan lempung ditemukan lapisan pasir (non-kohesif) hingga akhir pengeboran di kedalaman $16 \mathrm{~m}$. 


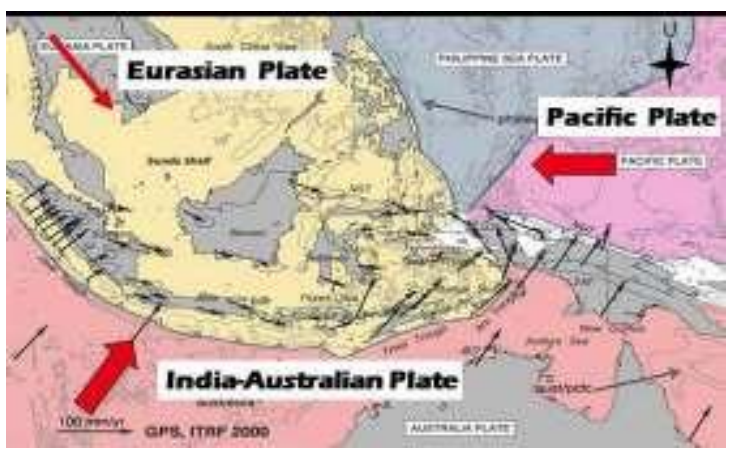

Gambar 1 Peta lempeng tektonik (Pusat Studi Gempa Nasional Indonesia, 2017)

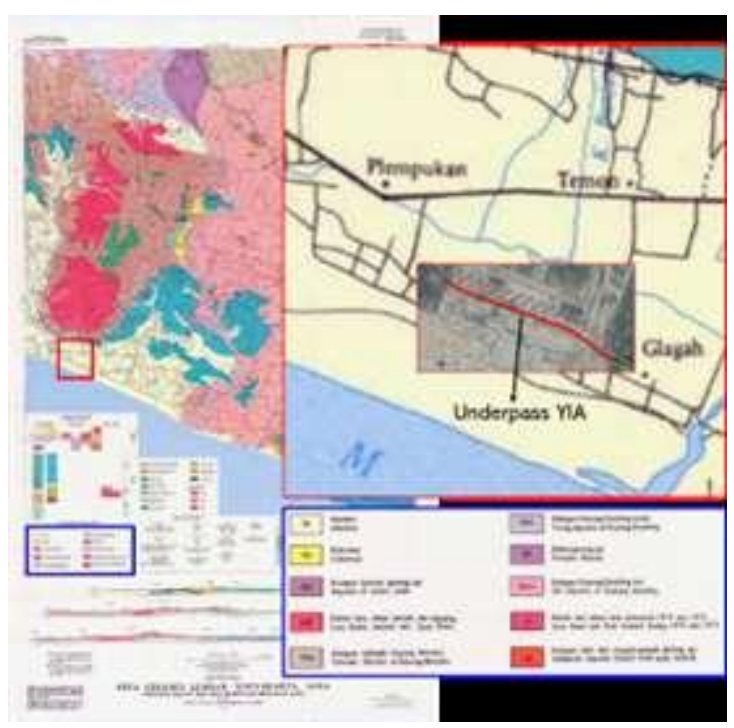

Gambar 2 Kondisi geologi regional kawasan Underpass YIA (Peta Geologi Lembar Yogyakarta Jawa, 1977)

Dengan menggunakan data bor sepanjang Underpass YIA dilakukan analisis potensi likuifaksi. Rahman (2019) menganalisis potensi likuifaksi pada Underpass YIA terjadi pada kedalaman 4-6 m dari permukaan tanah. Aktivitas seismik serta kondisi geologi dan geoteknik dari lapisan tanah menyebabkan wilayah Underpass YIA rentan terhadap gempa bumi berpotensi likuifaksi.

Pada saat gempa bumi terjadi, energi dilepaskan akibat pergerakan pada pertemuan lempeng tektonik kemudian di transfer menjadi energi gelombang gempa dari pusat gempa yang merambat ke segala arah sampai ke permukaan tanah. Sebelum mencapai alat pencatat gempa, gelombang gempa akan melewati bermacam-macam kondisi lapisan tanah, sebagian gelombang akan dipantulkan, dibiaskan, dan ada pula yang bergerak sepanjang permukaan tanah.

Tanah merupakan faktor penghantar penting selama gelombang gempa menjalar dari pusat gempa sampai ke permukaan tanah. Respon tanah terhadap gelombang gempa akan berlainan pada beberapa tempat yang disebabkan oleh beberapa faktor diantaranya adalah kondisi geologi, kondisi jenis tanah, frekuensi gempa, dan kedalaman lapisan tanah yang berpengaruh terhadap kekakuannya.

Penelitian ini dilakukan untuk menganalisis perubahan perilaku tanah berdasarkan kedalaman tanah dimana tanah tersebut berpotensi mengalami likuifaksi sehingga didapatkan perubahan simpangan tanah, kepadatan tanah, dan percepatan tanah tiap kedalaman lapisan tanah di kawasan Underpass YIA. Fenomena likuifaksi dapat diselidiki dengan mengevaluasi korelasi antara kedalaman tanah dan tegangan efektif tanah (Jalil dkk., 2020). Penelitian ini menggunakan data geoteknik di kawasan Underpass YIA dengan metode uji lapangan $N$-SPT (Standard Penetration Test) dan analisis perilaku lapisan tanah menggunakan metode analisis dinamika struktur Multi Degree of Freedom (MDOF) dengan pemodelan matematis lapisan tanah berupa model bangunan geser (shear building). Hasil akhir penelitian ini akan didapatkan perbedaan respon tanah yang mempunyai kekakuan berbeda jika mengalami getaran gempa dan berpotensi terjadi likuifaksi.

\section{METODE PENELITIAN}

\section{Analisis indeks propertis lapisan tanah}

Dalam penelitian ini, data penyelidikan tanah berupa hasil uji lapangan $S P T$ berjumlah 5 titik tinjauan yang tersebar di kawasan Underpass YIA. Pengeboran dan uji SPT memiliki peranan penting untuk mengetahui jenis dan karakteristik tanah wilayah penelitian berupa data indeks propertis tanah pada kedalaman tertentu (Gambar 3). Pada setiap lapisan tanah yang tidak diketahui nilai indeks propertis tanah, maka dilakukan beberapa asumsi berdasarkan korelasi yang diusulkan oleh Das (1985) dan Bowles (1984). 


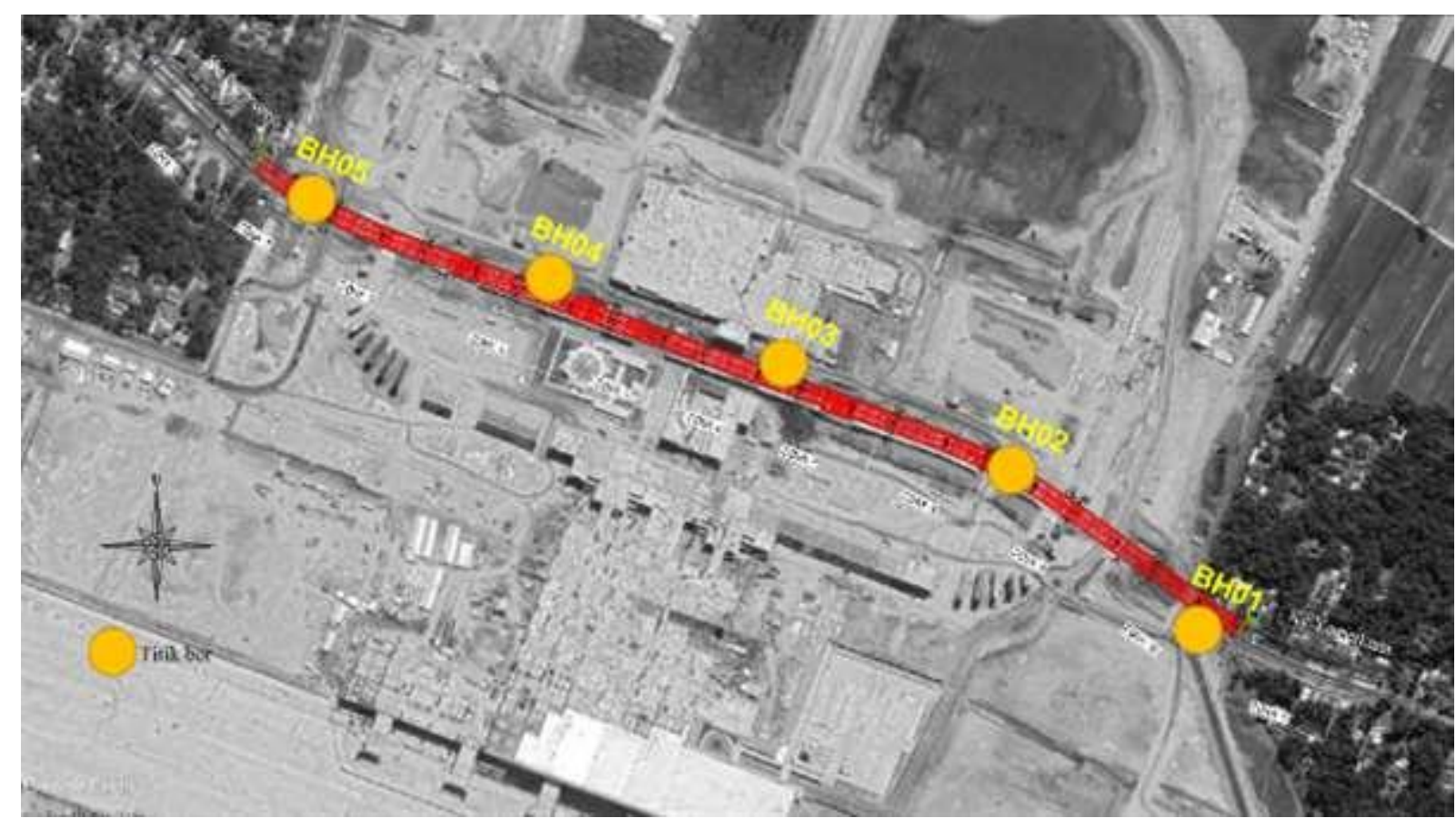

Gambar 3 Lokasi 5 titik tinjauan penelitian

Nilai angka pori ditentukan dengan menggunakan korelasi dimana untuk lapisan lempung kepasiran ditentukan angka pori sebesar $0,60(e=0,60)$ dan untuk lapisan pasir angka pori sebesar $0,45 \quad(e=45)$. Sedangkan untuk memperoleh nilai sudut gesek dalam $(\varphi)$ dan berat volume tanah $(\gamma)$ dilakukan dengan cara interpolasi nilai $N$-SPT. Hasil korelasi untuk nilai indeks propertis tanah pada titik pengujian BH01 ditunjukkan pada Tabel 1 . Cara yang sama diterapkan pada seluruh titik pengujian.

Tabel 1 Nilai indeks propertis tanah

\begin{tabular}{ccccccc}
\multicolumn{3}{l}{ Lokasi : BH01 } \\
MAT $: 4 \mathrm{~m}$
\end{tabular}

$\begin{array}{cccccccc}8 & & & & & 0 & \\ 8 & 10 & 60 & 23,0 & 13,2 & 0 & 0,45 \\ & & & & & 42, & \\ 9 & 12 & 60 & 23,0 & 13,2 & 0 & 0,45 \\ & & & & & 42, & 0,45 \\ 10 & 14 & 60 & 23,0 & 13,2 & 0 & \\ & & & & & 42, & 0,45 \\ 11 & 16 & 60 & 23,0 & 13,2 & 0 & \\ & & & & & & \end{array}$

Analisis propertis dinamik tanah

Pada pembebanan dinamik tanah diperlukan pengetahuan propertis tanah diantaranya adalah kecepatan gelombang geser $\left(v_{s}\right)$, modulus geser $(G)$, rasio redaman $(D)$, kekakuan tanah $(k)$ dan massa tanah $(m)$. Adapun dalam menentukan nilai propertis tanah tersebut menggunakan parameterparameter berdasarkan data indeks propertis tanah seperti yang ditunjukkan pada Tabel 1 . Contoh analisis perhitungan pada bagian selanjutnya dilakukan pada lokasi titik pengujian BH01. Cara yang sama diterapkan pada seluruh titik pengujian.

\section{ANALISIS DAN PEMBAHASAN \\ Kecepatan gelombang geser $\left(v_{s}\right)$}

Lokasi titik BH01 berada di sisi timur Underpass YIA. Kedudukan muka air tanah hasil pengujian lapangan berada pada kedalaman $4 \mathrm{~m}$. Besarnya tegangan efektif 
oktahendral $\left(\bar{\sigma}_{o}\right)$ pada setiap kedalaman adalah sebagai berikut :

1. Lapisan 1 (tebal $\mathrm{z}=1 \mathrm{~m})$

Tegangan efektif lapisan $1\left(\bar{\sigma}_{v l}\right)$ :

$\bar{\sigma}_{v 1}=\gamma \times z_{\text {lapl }}=14,00 \times 1=14,00 \mathrm{kN} / \mathrm{m}^{2}$

Tegangan efektif oktahendral $\left({ }^{\sigma}\right)$ :

$$
\begin{aligned}
\bar{\sigma}_{o} & =\frac{\sigma_{v 1}}{3}(3-2 \sin \varphi) \\
& =\frac{14,00}{3}(3-2 \sin 28,67) \\
& =9,52 \mathrm{kN} / \mathrm{m}^{2}
\end{aligned}
$$

2. Lapisan 2 (tebal $\mathrm{z}=2 \mathrm{~m})$

Tegangan efektif lapisan $2\left(\bar{\sigma}_{v 2}\right)$ :

$$
\begin{aligned}
\bar{\sigma}_{v 2} & =\bar{\sigma}_{v 1}+\left(\gamma \times z_{\text {lap } 2}\right) \\
& =14,00+(14,20 \times 2) \\
& =42,40 \mathrm{kN} / \mathrm{m}^{2}
\end{aligned}
$$

Tegangan efektif oktahendral $\left(\bar{\sigma}_{o}\right)$ :

$$
\begin{aligned}
\bar{\sigma}_{o} & =\frac{\sigma_{v 2}}{3}(3-2 \sin \varphi) \\
& =\frac{42,40}{3}(3-2 \sin 29,03) \\
& =28,68 \mathrm{kN} / \mathrm{m}^{2}
\end{aligned}
$$

3. Lapisan 3 (tebal $\mathrm{z}=1 \mathrm{~m}$ )

Tegangan efektif lapisan $3\left(\bar{\sigma}_{v 3}\right)$ :

$$
\begin{aligned}
\bar{\sigma}_{v 3} & =\bar{\sigma}_{v 2}+\left(\gamma \times z_{\text {lap } 3}\right) \\
& =42,40+(14,60 \times 1) \\
& =57,00 \mathrm{kN} / \mathrm{m}^{2}
\end{aligned}
$$

Tegangan efektif oktahendral $\left(\bar{\sigma}_{o}\right)$ :

$$
\begin{aligned}
\bar{\sigma}_{o} & =\frac{\sigma_{v 3}}{3}(3-2 \sin \varphi) \\
& =\frac{57,00}{3}(3-2 \sin 29,77) \\
& =38,13 \mathrm{kN} / \mathrm{m}^{2}
\end{aligned}
$$

4. Lapisan 4 (tebal $\mathrm{z}=1 \mathrm{~m})$

Tegangan efektif lapisan $4\left(\sigma^{v^{4}}\right)$ :

$$
\begin{aligned}
\bar{\sigma}_{v 4} & =\bar{\sigma}_{v 3}+\left(\gamma^{\prime} \times z_{\text {lap } 4}\right) \\
& =57,00+(5,59 \times 1) \\
& =62,59 \mathrm{kN} / \mathrm{m}^{2}
\end{aligned}
$$

Tegangan efektif oktahendral $\left(\bar{\sigma}_{o}\right)$ :

$$
\bar{\sigma}_{o}=\frac{\sigma_{v 4}}{3}(3-2 \sin \varphi)
$$

$$
\begin{aligned}
& =\frac{62,59}{3}(3-2 \sin 31,23) \\
& =40,96 \mathrm{kN} / \mathrm{m}^{2}
\end{aligned}
$$

Dari hasil perhitungan, tegangan efektif oktahendral $\left(\sigma_{o}\right)$ yang terjadi pada lapisan tanah yang berada di atas muka air tanah yakni kedalaman 1 meter sampai 4 meter berturutturut adalah $9,52 \mathrm{kN} / \mathrm{m}^{2}, 28,68 \mathrm{kN} / \mathrm{m}^{2}$, dan $38,13 \mathrm{kN} / \mathrm{m}^{2}$. Sedangkan tegangan efektif oktahendral $\left({ }^{\sigma_{o}}\right)$ yang terjadi pada lapisan dibawah muka air tanah yakni kedalaman 5 meter adalah 40,96 kN/m² (Tabel 2). Cara yang sama diterapkan pada seluruh titik pengujian.

Nilai tegangan efektif oktahendral $\left(\bar{\sigma}_{o}\right)$ yang diperoleh selanjutnya digunakan untuk menentukan nilai kecepatan gelombang geser $\left(v_{s}\right)$ berdasarkan persamaan Hardin dan Richart (1963):

1) Lapisan 1

$$
v_{s}=(11,36-5,35 e) \sigma_{0}^{-\left(\frac{1}{3}\right)}=16,02 \mathrm{~m} / \mathrm{s}
$$

2) Lapisan 4

$$
v_{s}=(11,36-5,35 e) \sigma_{0}^{-\left(\frac{1}{3}\right)}=27,27 \mathrm{~m} / \mathrm{s}
$$

3) Lapisan 11

$$
v_{s}=(19,7-9,06 e) \bar{\sigma}_{0}^{\left(\frac{1}{4}\right)}=51,17 \mathrm{~m} / \mathrm{s}
$$

Tabel 2 Hasil analisis tegangan efektif oktahendral $\left({ }^{\sigma_{o}}\right)$ tiap lapisan tanah

\begin{tabular}{cccccc}
\hline & $\mathrm{BH} 01$ & $\mathrm{BH} 02$ & $\mathrm{BH} 03$ & $\mathrm{BH} 04$ & $\mathrm{BH} 05$ \\
\cline { 2 - 6 } Lapisan & $\bar{\sigma}_{o}$ & $\bar{\sigma}_{o}$ & $\bar{\sigma}_{\theta}$ & $\bar{\sigma}_{o}$ & $\bar{\sigma}_{o}$ \\
& $\left(\mathrm{kN} / \mathrm{m}^{2}\right.$, & $\left(\mathrm{kN} / \mathrm{m}^{22},\left(\mathrm{kN} / \mathrm{m}^{2}\right)\right.$ & $\left(\mathrm{kN} / \mathrm{m}^{2}\right)$ & $\left(\mathrm{kN} / \mathrm{m}^{2}\right)$ \\
\hline 1 & 9.52 & 9.76 & 10.17 & 20.20 & 9.48 \\
2 & 28.68 & 30.00 & 30.28 & 40.32 & 28.43 \\
3 & 38.13 & 38.34 & 41.24 & 51.18 & 35.80 \\
4 & 40.96 & 42.13 & 46.14 & 58.49 & 38.65 \\
5 & 41.98 & 46.74 & 49.17 & 65.72 & 39.40 \\
6 & 49.28 & 49.75 & 54.50 & 79.42 & 44.13 \\
7 & 56.59 & 55.13 & 55.99 & 93.77 & 49.93 \\
8 & 71.20 & 69.75 & 69.59 & 107.42 & 64.20 \\
9 & 85.81 & 84.36 & 82.62 & 120.55 & 78.81 \\
10 & 100.42 & 98.97 & 96.38 & & 93.43 \\
11 & 115.04 & 113.58 & 110.99 & & 108.04 \\
\hline
\end{tabular}


Dari hasil perhitungan kecepatan gelombang geser $\left(v_{s}\right)$ pada lapisan 1 menggunakan nilai angka pori $(e)$ sebesar 0,60 diperoleh nilai kecepatan gelombang geser $\left(v_{s}\right)$ sebesar $16,02 \mathrm{~m} / \mathrm{s}$. Pada lapisan 4 diperoleh nilai kecepatan gelombang geser $\left(v_{s}\right)$ sebesar $27,27 \mathrm{~m} / \mathrm{s}$ dengan nilai angka pori $(e)$ sebesar 0,45 . Sedangkan pada lapisan 11 diperoleh nilai kecepatan gelombang geser $\left(v_{s}\right)$ sebesar $49,46 \mathrm{~m} / \mathrm{s}$ dengan menggunakan nilai angka pori (e) sebesar 0,45 (Tabel 3). Dengan cara yang sama nilai kecepatan gelombang geser $\left(v_{s}\right)$ pada seluruh titik pengujian dapat diperoleh yang ditunjukkan oleh Tabel 4 Tabel 7.

\section{Penentuan modulus geser}

Modulus geser $(G)$ termasuk salah satu parameter penting pada perilaku tanah akibat beban dinamik. Pada analisis ini dilakukan contoh perhitungan pada titik BH01 di lapisan 1, lapisan 4, dan lapisan 11 sebagai berikut:

1) Lapisan 1

$$
\begin{aligned}
G & =\rho v_{s}^{2} \\
G & =\left(\frac{\gamma^{\prime} \times 1000}{9,81}\right)=\left(\frac{14,00 \times 1000}{9,81}\right) \\
& =366,45 \mathrm{kN} / \mathrm{m}^{2}
\end{aligned}
$$

Berdasarkan identifikasi dengan metode USCS, tanah lempung plastisitas tinggi diambil nilai Plastisitas Indeks $(P I)=60 \%$. Dengan demikian didapat nilai koefisien konstan, $K=$ 0,41 . Sehingga nilai modulus geser maksimum $\left(G_{\text {maks }}\right)$ dapat diperoleh menggunakan persamaan yang dikembangkan Hardin dan Drnevich (1972):

$$
\begin{aligned}
& G_{\text {maks }}=\frac{1230 \times(2,97-e)^{2}}{1+e}(\text { OCR })^{K_{-}^{-}} \sigma_{0}^{\left(\frac{1}{2}\right)} \\
& G_{\text {maks }}=\frac{1230 \times(2,97-0,60)^{2}}{1+0,60} \times(1)^{0,41} \times 9,52 \\
& \mathrm{G}_{\text {maks }}={ }_{13324,49 \mathrm{kN} / \mathrm{m}^{2}}
\end{aligned}
$$

dimana $O C R($ over consolidation ratio $)=1$

2) Lapisan 4

$$
\text { a. } \begin{aligned}
G & =\rho v_{s}{ }^{2} \\
G & =\left(\frac{\gamma^{\prime} \times 1000}{9,81}\right)=\left(\frac{5,59 \times 1000}{9,81}\right)
\end{aligned}
$$

$$
=423,66 \mathrm{kN} / \mathrm{m}^{2}
$$

b. Nilai modulus geser maksimum $\left(G_{\text {maks }}\right)$ :

$$
\begin{aligned}
G_{\text {maks }} & =\frac{6908 \times(2,17-e)^{2}-\left(\frac{1}{2}\right)}{1+e} \sigma_{0} \\
G_{\text {maks }} & =\frac{6908 \times(2,17-0,45)^{2}}{1+0,45} \times 40,966^{\left(\frac{1}{2}\right)} \\
G_{\text {maks }} & =90198,39 \mathrm{kN} / \mathrm{m}^{2}
\end{aligned}
$$

3) Lapisan 11

a) $\mathrm{G}=\rho v_{s}^{2}$

$$
\begin{aligned}
G & =\left(\frac{\gamma^{\prime} \times 1000}{9,81}\right)=\left(\frac{13,19 \times 1000}{9,81}\right) \\
& =3519,84 \mathrm{kN} / \mathrm{m}^{2}
\end{aligned}
$$

b) Nilai modulus geser maksimum $\left(G_{\text {maks }}\right)$ :

$$
\begin{aligned}
G_{\text {maks }} & =\frac{6908 \times(2,17-e)^{2}-\left(\frac{1}{2}\right)}{1+e} \sigma_{0} \\
G_{\text {maks }} & =\frac{6908 \times(2,17-0,45)^{2}}{1+0,45} \times 115,04 \\
G_{\text {maks }} & =\frac{\left(\frac{1}{2}\right)}{151167,81 \mathrm{kN} / \mathrm{m}^{2}}
\end{aligned}
$$

Cara yang sama diterapkan pada seluruh titik pengujian. Hasil perhitungan nilai modulus geser ( $G$ ) dan modulus geser maksimum $\left(G_{\text {maks }}\right)$ setiap lapisan pada seluruh titik pengujian dapat dilihat pada Tabel 3 Tabel 7.

\section{Rasio redaman}

\section{1) Lapisan 1}

Pada penelitian jumlah $N$ siklik sebesar 8 siklik berdasarkan gempa Yogyakarta 2006 sebesar 6,3 SR. Nilai frekuensi natural $(f)$ pada lapisan ini ditentukan dengan persamaan sebagai berikut:

$\begin{aligned} f=\frac{\omega_{n}}{2 \pi} & =\frac{\sqrt{\frac{k}{m}}}{2 \pi}=\frac{\sqrt{\frac{91,61}{0,71}}}{2 \times 3,14}=1,80 \mathrm{cps} \\ \text { Nilai } & \text { redaman maksimum }\left(D_{\text {maks }}\right)\end{aligned}$ ditentukan oleh persamaan berikut:

$D_{\text {maks }}(\%)=31-(0,3+0,003 f) \bar{\sigma}_{0}^{\left(\frac{1}{2}\right)}+1,5 f^{\left(\frac{1}{2}\right)}-1,5(\log N)$

$D_{\text {maks }}(\%)=31,56 \%$ 
Nilai redaman (D) ditentukan menggunakan persamaan: $D$

$$
=D_{\text {maks }}\left(1-\frac{G}{G_{\text {maks }}}\right)=30,69 \%
$$

2) Lapisan 4

Tahap pertama tentukan nilai $F^{\prime}$ dengan menggunakan persamaan:

$$
F^{\prime}=\frac{G}{G_{\text {maks }}}=\frac{423,66}{90198,39}=0,01
$$

Sesuai dengan Gambar 4, untuk nilai $F^{\prime}=$ 0,01 diperoleh nilai regangan geser, $\gamma^{\prime}=1 \%$. Nilai rasio redaman tanah pasir, $D=25 \%$ untuk $\gamma^{\prime}=1 \%$ sesuai dengan Gambar 5 .

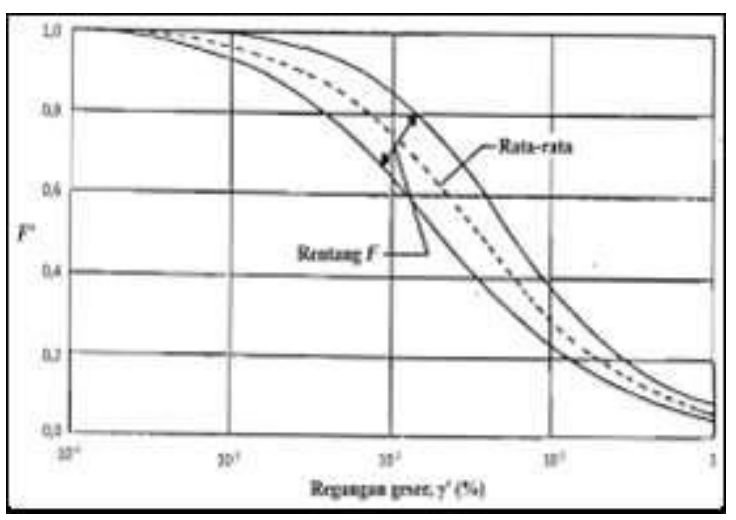

Gambar 4 Variasi nilai $F^{\prime}$ dengan regangan geser $\left(\gamma^{\prime}\right)$ untuk pasir (Seed dkk., 1986)

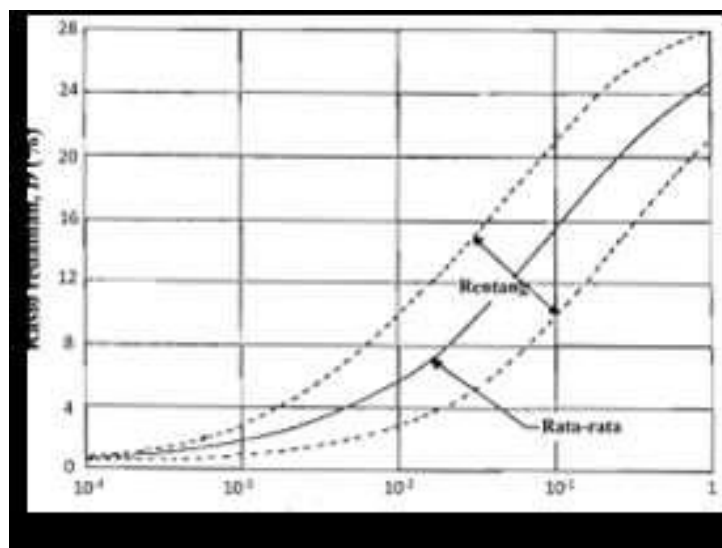

Gambar 5 Hubungan regangan geser $\left(\gamma^{\prime}\right)$ dengan rasio redaman $(D)$ untuk pasir (Seed dkk., 1986)

Dengan mengetahui nilai rasio redaman untuk pasir $(D)$, maka nilai rasio redaman maksimum ( $\left.D_{\text {maks }}\right)$ dapat dihitung dengan persamaan:

$$
D_{\text {maks }}=D+\left(1-\frac{G}{G_{\text {maks }}}\right)=25,12 \%
$$

3) Lapisan 11
Tahap pertama tentukan nilai $F^{\prime}$ dengan menggunakan persamaan:

$$
F^{\prime}=\frac{G}{G_{\text {maks }}}=\frac{3519,84}{151167,81}=0,02
$$

Sesuai dengan Gambar 4, untuk nilai $F^{\prime}=$ 0,02 diperoleh nilai regangan geser, $\gamma^{\prime}=1 \%$.

Nilai rasio redaman tanah pasir, $D=25 \%$ untuk $\gamma^{\prime}=1 \%$ sesuai dengan Gambar 5 .

Dengan mengetahui nilai rasio redaman untuk pasir $(D)$, maka nilai rasio redaman maksimum ( $\left.D_{\text {maks }}\right)$ dapat dihitung dengan persamaan:

$D_{\text {maks }}=D+\left(1-\frac{G}{G_{\text {maks }}}\right)=25,60 \%$

Hasil perhitungan menunjukkan bahwa nilai rasio redaman $(D)$ pada titik $\mathrm{BH} 01$ dimulai dari lapisan 3 bernilai konsisten sebesar $25 \%$. Sedangkan untuk nilai rasio redaman maksimum $\left(D_{\text {maks }}\right)$ di titik BH01 pada lapisan 1, lapisan 4, dan lapisan 11 secara berturut-turut sebesar $31,56 \%, 25,12 \%$, dan $25,60 \%$. Adapun nilai rata-rata rasio redaman $(\bar{D})$ titik BH01 sebesar 26,13\%. Nilai rata-rata rasio redaman $(\bar{D})$ pada titik pengujian $\mathrm{BH} 02$ BH05 diperoleh dengan menggunakan cara yang sama. Hasil analisis rasio redaman $(D)$ tiap lapisan pada seluruh titik pengujian ditunjukkan pada Tabel 3 - Tabel 7.

\section{Kekakuan tanah}

Contoh perhitungan kekakuan tanah $(k)$ dilakukan pada titik pengujian BH01 sebagai berikut:

1) Lapisan 1

$$
k_{1}=\frac{G_{1}}{2 h_{1}}=\frac{366,45}{2 \times 0,5}=91,61 \mathrm{kN} / \mathrm{m}^{2}
$$

2) Lapisan 2

$$
k_{2}=\frac{G_{2}}{2 h_{2}}=\frac{720,29}{2 \times 1}=360,15 \mathrm{kN} / \mathrm{m}^{2}
$$

3) Lapisan 3

$$
k_{3}=\frac{G_{3}}{2 h_{3}}=\frac{1060,10}{2 \times 0,5}=265,03 \mathrm{kN} / \mathrm{m}^{2}
$$

Hasil perhitungan kekakuan tanah $(k)$ diperoleh nilai di lapisan 1 sampai dengan lapisan 4 berturut-turut sebesar $91,61 \mathrm{kN} / \mathrm{m}^{2}$, $360,15 \mathrm{kN} / \mathrm{m}^{2}, 265,03 \mathrm{kN} / \mathrm{m}^{2}, 105,92 \mathrm{kN} / \mathrm{m}^{2}$. 
Cara yang sama diterapkan pada titik pengujian $\mathrm{BH} 02-\mathrm{BH} 05$. Hasil analisis nilai kekakuan tanah $(k)$ seluruh titik pengujian ditunjukkan pada Tabel 3 - Tabel 7.

\section{Analisis massa tanah}

Penentuan nilai massa tanah $(\mathrm{m})$ dilakukan dengan menggunakan metode yang dikembangkan Idriss dan Seed (1968). Contoh perhitungan penentuan nilai massa tanah $(\mathrm{m})$ digunakan lokasi titik BH01 sebagai berikut:

1) Lapisan 1

$$
m_{1}=\frac{\gamma_{1} h_{1}}{g}=\frac{14,00 \times 0,5}{9,81}=0,71 \mathrm{ton} / \mathrm{m}^{2}
$$

2) Lapisan 2

$$
\begin{aligned}
m_{2} & =m_{1}+\frac{\gamma_{2} h_{2}}{g} \\
& =0,71+\frac{14,20 \times 1}{9,81}=2,16 \mathrm{ton} / \mathrm{m}^{2}
\end{aligned}
$$

3) Lapisan 3

$$
\begin{aligned}
m_{3} & =m_{2}+\frac{\gamma_{3} h_{3}}{g} \\
& =2,16+\frac{14,60 \times 0,5}{9,81}=2,91 \mathrm{ton} / \mathrm{m}^{2}
\end{aligned}
$$

Hasil perhitungan menunjukkan bahwa nilai massa tanah $(\mathrm{m})$ pada lapisan 1 - lapisan 4 berturut-turut sebesar $0,71 \mathrm{ton} / \mathrm{m}^{2}, 2,16$ ton $/ \mathrm{m}^{2}, 2,91$ ton $/ \mathrm{m}^{2}$, dan 3,69 ton $/ \mathrm{m}^{2}$. Semakin dalam lapisan tanah maka nilai massa tanah $(m)$ semakin besar. Hal ini disebabkan massa tanah $(m)$ dipengaruhi oleh berat volume tanah $(\gamma)$ dan merupakan akumulasi dari massa tanah (m) pada lapisan tanah diatasnya. Tabel 3 Tabel 7 menampilkan rekapitulasi hasil analisis massa tanah $(m)$ pada setiap lapisan tanah pada seluruh titik pengujian.

Tabel 3 Hasil analisis dinamik propertis tanah setiap lapisan di titik pengujian BH01

\begin{tabular}{cccccccc}
\hline Lapisan & $\begin{array}{c}v_{s} \\
(\mathrm{~m} / \mathrm{s})\end{array}$ & $\begin{array}{c}G \\
\left(\mathrm{kN} / \mathrm{m}^{2}\right)\end{array}$ & $\begin{array}{c}G_{\text {maks }} \\
\left(\mathrm{kN} / \mathrm{m}^{2}\right)\end{array}$ & $\begin{array}{c}D \\
(\%)\end{array}$ & $\begin{array}{c}D_{\text {maks }} \\
(\%)\end{array}$ & $\begin{array}{c}m \\
\left(\mathrm{ton} / \mathrm{m}^{2}\right)\end{array}$ & $\begin{array}{c}k \\
\left(\mathrm{kN} / \mathrm{m}^{3}\right)\end{array}$ \\
\hline 1 & 16,02 & 366,45 & 13324,49 & 30,69 & 31,56 & 0,71 & 91,61 \\
2 & 22,31 & 720,29 & 23125,70 & 30,64 & 31,62 & 2,16 & 360,15 \\
3 & 26,69 & 1060,10 & 87033,71 & 25,00 & 25,31 & 2,91 & 265,03 \\
4 & 27,27 & 423,66 & 90198,39 & 25,00 & 25,12 & 3,69 & 105,92 \\
5 & 27,47 & 1014,52 & 91314,40 & 25,00 & 25,28 & 4,86 & 253,63 \\
6 & 28,82 & 1117,06 & 98942,70 & 25,00 & 25,29 & 6,03 & 279,26 \\
7 & 30,04 & 1213,66 & 106023,57 & 25,00 & 25,29 & 7,21 & 303,42 \\
8 & 32,19 & 1393,00 & 118927,18 & 25,00 & 25,30 & 9,55 & 696,50 \\
9 & 34,04 & 1558,09 & 130561,68 & 25,00 & 25,30 & 11,90 & 779,05 \\
10 & 49,46 & 3288,70 & 141241,03 & 25,00 & 25,60 & 14,24 & 1644,35 \\
11 & 51,17 & 3519,84 & 151167,81 & 25,00 & 25,60 & 16,59 & 1759,92 \\
\hline
\end{tabular}

Tabel 4 Hasil analisis dinamik propertis tanah setiap lapisan di titik pengujian BH02

\begin{tabular}{cccccccc}
\hline Lapisan & $\begin{array}{c}v_{s} \\
(\mathrm{~m} / \mathrm{s})\end{array}$ & $\begin{array}{c}G \\
\left(\mathrm{kN} / \mathrm{m}^{2}\right)\end{array}$ & $\begin{array}{c}G_{\text {maks }} \\
\left(\mathrm{kN} / \mathrm{m}^{2}\right)\end{array}$ & $\begin{array}{c}D \\
(\%)\end{array}$ & $\begin{array}{c}D_{\text {maks }} \\
(\%)\end{array}$ & $\begin{array}{c}m \\
\left(\mathrm{ton} / \mathrm{m}^{2}\right)\end{array}$ & $\begin{array}{c}k \\
\left(\mathrm{kN} / \mathrm{m}^{3}\right)\end{array}$ \\
\hline 1 & 16.14 & 377.13 & 13486.84 & 30.69 & 31.57 & 0.72 & 94.28 \\
2 & 22.61 & 850.47 & 23651.49 & 30.52 & 31.66 & 2.39 & 425.23 \\
3 & 26.73 & 504.85 & 87273.63 & 25.00 & 25.15 & 3.24 & 126.21 \\
4 & 27.50 & 597.44 & 91485.20 & 25.00 & 25.16 & 4.14 & 149.36 \\
5 & 28.37 & 654.73 & 96362.45 & 25.00 & 25.17 & 5.04 & 163.68 \\
6 & 28.91 & 850.06 & 99416.39 & 25.00 & 25.22 & 6.05 & 212.52 \\
7 & 29.81 & 1194.87 & 104653.62 & 25.00 & 25.29 & 7.22 & 298.72 \\
8 & 31.99 & 1375.88 & 117707.51 & 25.00 & 25.30 & 9.57 & 687.94 \\
9 & 33.87 & 1542.21 & 129451.67 & 25.00 & 25.30 & 11.91 & 771.11 \\
10 & 49.28 & 3264.82 & 140215.59 & 25.00 & 25.60 & 14.26 & 1632.41 \\
11 & 51.00 & 3497.54 & 150210.15 & 25.00 & 25.60 & 16.60 & 1748.77 \\
\hline
\end{tabular}

Tabel 5 Hasil analisis dinamik propertis tanah setiap lapisan di titik pengujian BH03

\begin{tabular}{cccccccc}
\hline \multirow{2}{*}{ Lapisan } & $\begin{array}{c}v_{s} \\
(\mathrm{~m} / \mathrm{s})\end{array}$ & $\begin{array}{c}G \\
\left(\mathrm{kN} / \mathrm{m}^{2}\right)\end{array}$ & $\begin{array}{c}G_{\text {maks }} \\
\left(\mathrm{kN} / \mathrm{m}^{2}\right)\end{array}$ & $\begin{array}{c}D \\
(\%)\end{array}$ & $\begin{array}{c}D_{\text {maks }} \\
(\%)\end{array}$ & $\begin{array}{c}m \\
\left(\mathrm{ton} / \mathrm{m}^{2}\right)\end{array}$ & $\begin{array}{c}k \\
\left(\mathrm{kN} / \mathrm{m}^{3}\right)\end{array}$ \\
\hline
\end{tabular}


Vol. 4 No.1 Januari 2021

Rang Teknik Journal

http://jurnal.umsb.ac.id/index.php/RANGTEKNIKJOURNAL

\begin{tabular}{cccccccc}
\hline 1 & 16.34 & 421.14 & 13767.53 & 30.61 & 31.58 & 0.79 & 105.28 \\
2 & 22.67 & 799.58 & 23759.22 & 30.57 & 31.63 & 2.34 & 399.79 \\
3 & 24.87 & 1002.18 & 27728.57 & 30.10 & 31.23 & 3.15 & 250.54 \\
4 & 25.73 & 439.20 & 29330.05 & 30.34 & 30.80 & 3.99 & 109.80 \\
5 & 28.80 & 657.11 & 98825.94 & 25.00 & 25.17 & 4.88 & 164.28 \\
6 & 29.71 & 726.85 & 104045.01 & 25.00 & 25.18 & 5.79 & 181.71 \\
7 & 29.95 & 1205.89 & 105457.48 & 25.00 & 25.29 & 6.97 & 301.47 \\
8 & 31.97 & 1188.55 & 117571.06 & 25.00 & 25.26 & 9.13 & 594.27 \\
9 & 33.66 & 1369.52 & 128113.22 & 25.00 & 25.27 & 11.34 & 684.76 \\
10 & 48.95 & 3221.74 & 138365.12 & 25.00 & 25.60 & 13.68 & 1610.87 \\
11 & 50.71 & 3457.35 & 148484.28 & 25.00 & 25.60 & 16.03 & 1728.68 \\
\hline
\end{tabular}

Tabel 6 Hasil analisis dinamik propertis tanah setiap lapisan di titik pengujian BH04

\begin{tabular}{cccccccc}
\hline Lapisan & $\begin{array}{c}v_{s} \\
(\mathrm{~m} / \mathrm{s})\end{array}$ & $\begin{array}{c}G \\
\left(\mathrm{kN} / \mathrm{m}^{2}\right)\end{array}$ & $\begin{array}{c}G_{\text {maks }} \\
\left(\mathrm{kN} / \mathrm{m}^{2}\right)\end{array}$ & $\begin{array}{c}D \\
(\%)\end{array}$ & $\begin{array}{c}D_{\text {maks }} \\
(\%)\end{array}$ & $\begin{array}{c}m \\
\left(\mathrm{ton} / \mathrm{m}^{2}\right)\end{array}$ & $\begin{array}{c}k \\
\left(\mathrm{kN} / \mathrm{m}^{3}\right)\end{array}$ \\
\hline 1 & 20.08 & 637.84 & 50959.19 & 31.36 & 31.76 & 0.79 & 159.46 \\
2 & 24.71 & 935.81 & 67573.46 & 31.26 & 31.70 & 2.32 & 467.90 \\
3 & 29.15 & 1142.74 & 100834.63 & 25.00 & 25.29 & 4.67 & 571.37 \\
4 & 30.34 & 1237.98 & 107791.28 & 25.00 & 25.29 & 5.84 & 309.50 \\
5 & 31.42 & 1148.45 & 114256.53 & 25.00 & 25.25 & 6.92 & 287.11 \\
6 & 33.26 & 1487.41 & 125607.00 & 25.00 & 25.30 & 9.27 & 743.71 \\
7 & 34.96 & 1559.82 & 136484.67 & 25.00 & 25.29 & 11.54 & 779.91 \\
8 & 50.30 & 2942.24 & 146074.31 & 25.00 & 25.51 & 13.71 & 1471.12 \\
9 & 51.77 & 3603.13 & 154744.91 & 25.00 & 25.60 & 16.05 & 1801.56 \\
\hline
\end{tabular}

Tabel 7 Hasil analisis dinamik propertis tanah setiap lapisan di titik pengujian BH05

\begin{tabular}{cccccccc}
\hline Lapisan & $\begin{array}{c}v_{s} \\
(\mathrm{~m} / \mathrm{s})\end{array}$ & $\begin{array}{c}G \\
\left(\mathrm{kN} / \mathrm{m}^{2}\right)\end{array}$ & $\begin{array}{c}G_{\text {maks }} \\
\left(\mathrm{kN} / \mathrm{m}^{2}\right)\end{array}$ & $\begin{array}{c}D \\
(\%)\end{array}$ & $\begin{array}{c}D_{\text {maks }} \\
(\%)\end{array}$ & $\begin{array}{c}m \\
\left(\mathrm{ton} / \mathrm{m}^{2}\right)\end{array}$ & $\begin{array}{c}k \\
\left(\mathrm{kN} / \mathrm{m}^{3}\right)\end{array}$ \\
\hline 1 & 16.00 & 363.34 & 13293.34 & 30.70 & 31.56 & 0.71 & 90.83 \\
2 & 22.25 & 702.39 & 23024.75 & 30.66 & 31.62 & 2.13 & 351.20 \\
3 & 26.19 & 309.71 & 84331.01 & 25.00 & 25.09 & 2.85 & 77.43 \\
4 & 26.80 & 347.72 & 87627.80 & 25.00 & 25.10 & 3.60 & 86.93 \\
5 & 26.95 & 683.46 & 88468.08 & 25.00 & 25.19 & 4.57 & 170.87 \\
6 & 27.89 & 807.71 & 93632.02 & 25.00 & 25.22 & 5.59 & 201.93 \\
7 & 28.94 & 1049.91 & 99593.39 & 25.00 & 25.27 & 6.71 & 262.48 \\
8 & 31.20 & 1309.17 & 112931.94 & 25.00 & 25.29 & 9.06 & 654.58 \\
9 & 33.18 & 1480.57 & 125125.14 & 25.00 & 25.30 & 11.40 & 740.28 \\
10 & 34.92 & 1639.64 & 136231.34 & 25.00 & 25.30 & 13.75 & 819.82 \\
11 & 50.37 & 3411.10 & 146497.97 & 25.00 & 25.60 & 16.09 & 1705.55 \\
\hline
\end{tabular}

Respon dinamika tanah

Pada penelitian ini lapisan tanah dimodelkan sebagai shear building dengan anggapan bahwa lapisan tanah seakan-akan bangunan yang pola goyangannya didominasi oleh geser (shear mode), dan analisis perilaku dinamika tanah dilakukan dengan menggunakan metode dinamika struktur MDOF (Suhendro, 2000). Contoh perhitungan dan analisis perilaku dinamika tanah dengan metode $M D O F$ dilakukan pada lokasi titik pengujian $\mathrm{BH} 01$.
Persamaan diferensial gerakan struktur MDOF

Pada analisis ini digunakan prinsip kesetimbangan dinamik dengan model struktur $M D O F$, maka ditentukan persamaan simultan gerakan massa. Dalam persamaan tersebut terdapat matriks massa $[\mathrm{M}]$ dan kekakuan tanah [K]. Massa setiap lapisan tanah dianggap terkonsentrasi pada 1-titik (lumped mass). Pada proses analisis gerakan struktur $M D O F$ untuk keperluan perhitungan dan analisis, lapisan tanah paling atas dianggap menjadi lapisan tanah paling bawah, demikian juga sebaliknya. Maka diperoleh matriks massa [M] dan matrik kekakuan tanah $[\mathrm{K}]$ titik pengujian 
BH01 yang terdiri dari 11 lapisan tanah sebagai berikut :

a) Matriks massa

$$
[M]=\left|\begin{array}{ccccccccccc}
16,59 & 0 & 0 & 0 & 0 & 0 & 0 & 0 & 0 & 0 & 0 \\
0 & 14,24 & 0 & 0 & 0 & 0 & 0 & 0 & 0 & 0 & 0 \\
0 & 0 & 11,90 & 0 & 0 & 0 & 0 & 0 & 0 & 0 & 0 \\
0 & 0 & 0 & 9,55 & 0 & 0 & 0 & 0 & 0 & 0 & 0 \\
0 & 0 & 0 & 0 & 7,21 & 0 & 0 & 0 & 0 & 0 & 0 \\
0 & 0 & 0 & 0 & 0 & 6,03 & 0 & 0 & 0 & 0 & 0 \\
0 & 0 & 0 & 0 & 0 & 0 & 4,86 & 0 & 0 & 0 & 0 \\
0 & 0 & 0 & 0 & 0 & 0 & 0 & 3,69 & 0 & 0 & 0 \\
0 & 0 & 0 & 0 & 0 & 0 & 0 & 0 & 2,91 & 0 & 0 \\
0 & 0 & 0 & 0 & 0 & 0 & 0 & 0 & 0 & 2,16 & 0 \\
0 & 0 & 0 & 0 & 0 & 0 & 0 & 0 & 0 & 0 & 0,71
\end{array}\right|
$$

b) Matriks kekakuan tanah 


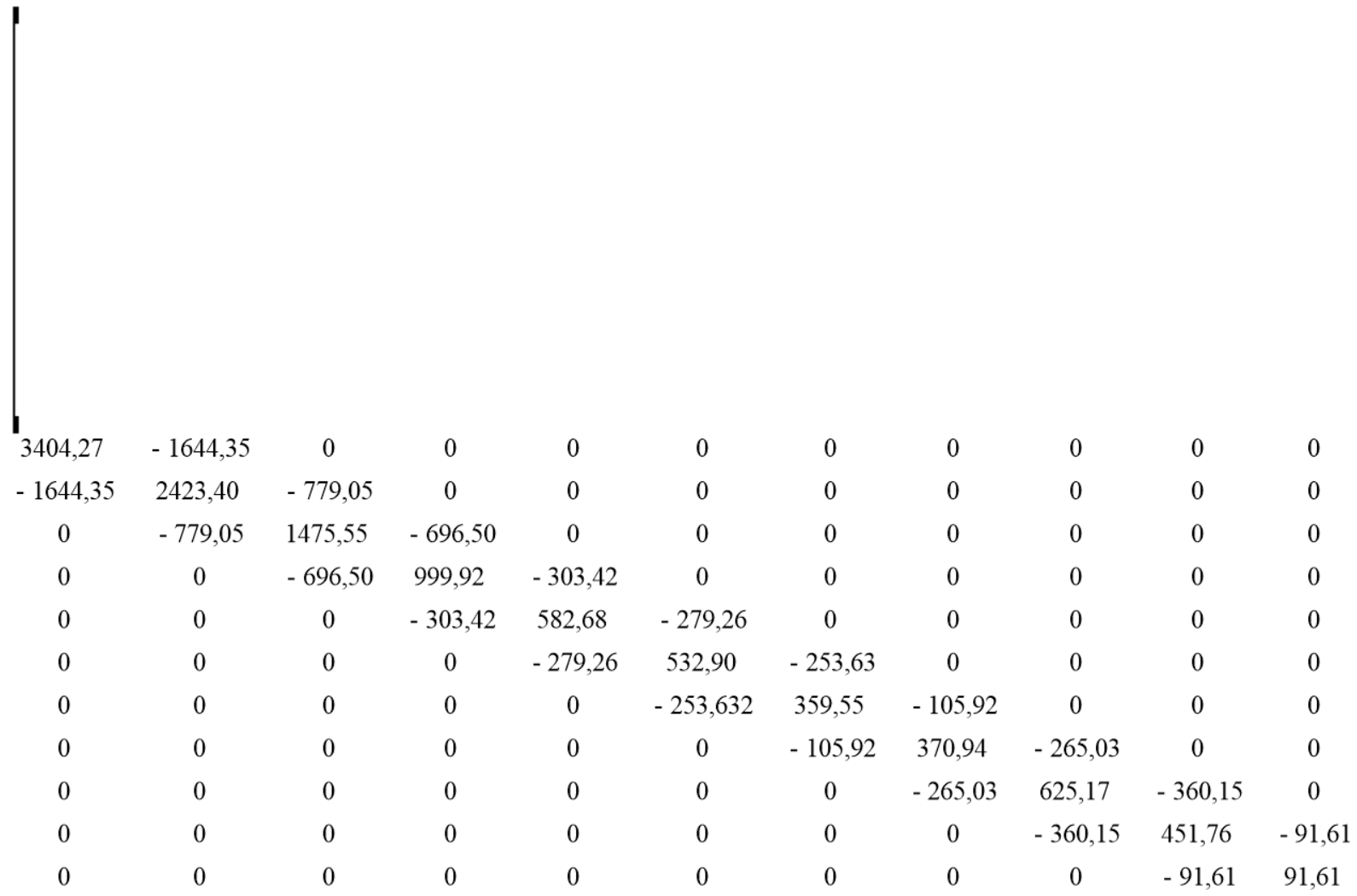

Penyelesaian Persamaan Eigenproblem

Pada proses analisis sistem $M D O F$ akan ditentukan nilai frekuensi sudut $(\omega)$ dan mode shape $(\phi)$ setiap lapisan tanah dengan menggunakan persamaan eigenproblem. Persamaan eigenproblem adalah persamaan simultan homogen yang dapat diselesaikan dengan memakai dalil/hukum Cramer (Pawirodikromo, 2017). Untuk mempermudah perhitungan digunakan program komputer MATLAB.

Tentukan Persamaan Eigenproblem lokasi titik BH01. Dalil Cramer yang menyatakan bahwa penyelesaian persamaan simultan yang homogen akan ada nilainya apabila determinan dari matriks yang merupakan koefisien dari vektor $(\phi)$ adalah nol, diolah menggunakan MATLAB sehingga diperoleh nilai frekuensi sudut $(\omega)$. Dengan diperolehnya nilai frekuensi sudut $(\omega)$, maka akan diperoleh nilai periode getar $(T)$ setiap mode dengan menggunakan persamaan berikut:

$T_{i}=\frac{2 \pi}{\omega}$ 
Tabel 8 menunjukkan nilai frekuensi sudut $(\omega)$ dan periode getar $(T)$. Adapun Gambar 6 dan Gambar 7 menunjukkan plot frekuensi sudut $(\omega)$ dan plot periode getar $(T)$ setiap mode.

Persamaan eigenproblem kemudian disederhanakan menjadi persamaan aljabar biasa dan diambil nilai mode shape pada mode kesatu sebesar $1 \quad\left(\phi_{1}=1\right)$. Sebagai contoh perhitungan diambil satu mode shape secara acak karena proses perhitungan menggunakan metode yang sama untuk setiap mode shape.

Dengan substitusi nilai ${ }^{\phi_{1}}$ kedalam persamaan aljabar yang ditunjukkan pada Tabel 9, maka akan diperoleh nilai-nilai ordinat tiap mode shape.

Tabel 8 Nilai frekuensi sudut $(\omega)$ dan periode getar $(T)$ titik BH01

\begin{tabular}{ccc}
\hline Mode ke- & $\omega(\mathrm{rad} / \mathrm{dt})$ & $T$ (detik) \\
\hline 1 & 0,686 & 9,157 \\
2 & 2,051 & 3,062 \\
3 & 3,231 & 1,944 \\
4 & 4,968 & 1,264 \\
5 & 7,513 & 0,836 \\
6 & 9,376 & 0,670 \\
7 & 13,342 & 0,471 \\
8 & 16,373 & 0,384 \\
9 & 20,284 & 0,310 \\
10 & 31,909 & 0,197 \\
11 & 81,179 & 0,077 \\
\hline
\end{tabular}

Nilai-nilai ordinat mode shape ( $\left.\phi_{i j}\right)$ selanjutnya diplot seperti pada Gambar 8 untuk mengetahui ragam goyangan untuk struktur tanah pada titik BH01.

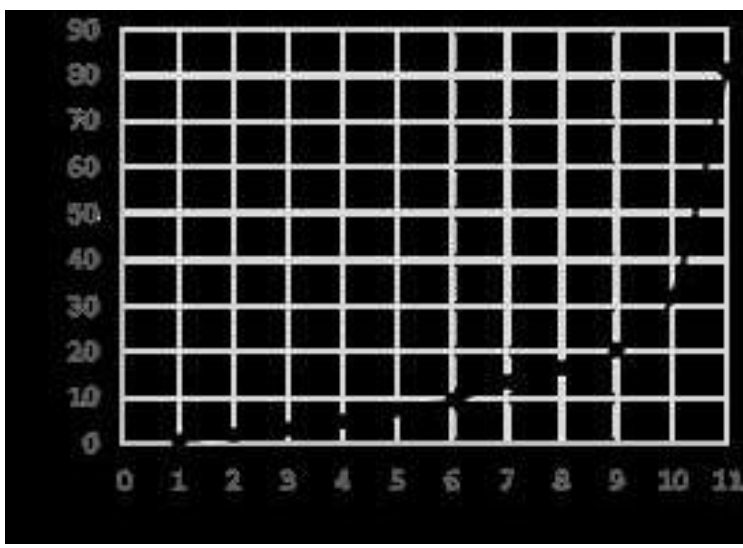

Gambar 6 Frekuensi sudut tiap mode titik BH01

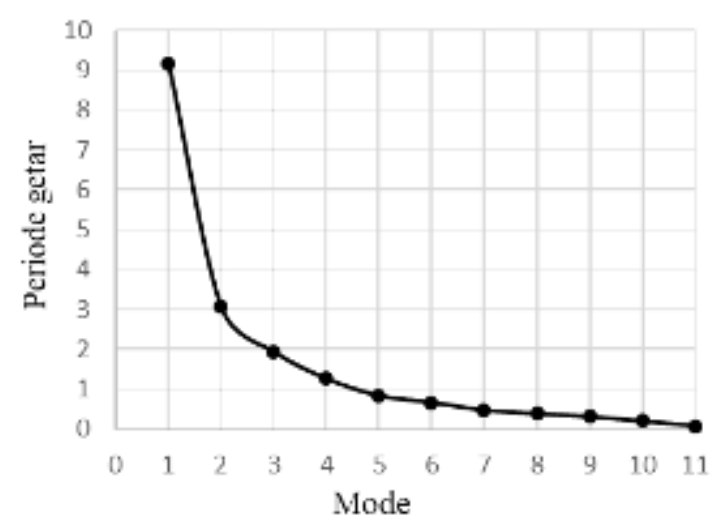

Gambar 7 Periode getar tiap mode titik BH01

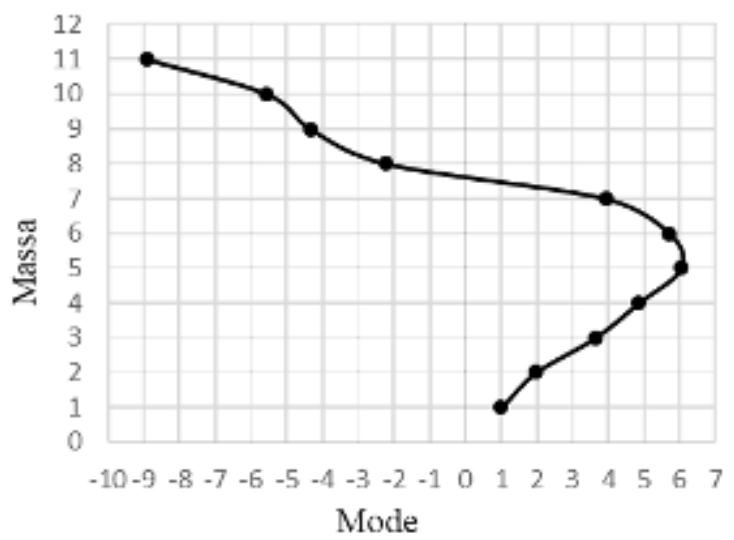

Gambar 8 Mode shape ke-3 struktur tanah $\mathrm{BH} 01$

Tabel 4 Perhitungan mode shape

\begin{tabular}{ccc}
\hline No & Fungsi $\phi$ & $\begin{array}{c}\text { Nilai } \phi_{\mathrm{ij}} \\
\text { Mode ke-3 } \\
\omega_{3}=3.231\end{array}$ \\
\hline 1 & $\phi_{1}=1,000$ & $\phi_{13}=1,000$ \\
2 & $\phi_{2}=2,070-0,01009 \omega^{2}$ & $\phi_{23}=1,965$ \\
3 & $\phi_{3}=-2,111+\left(3,111-0,01828 \omega^{2}\right) \phi_{2}$ & $\phi_{33}=3,627$ \\
4 & $\phi_{4}=-1,119 \phi_{2}+\left(2,119-0,01708 \omega^{2}\right) \phi_{3}$ & $\phi_{43}=4,839$
\end{tabular}


5

6

7

8

9

10

11

$$
\begin{aligned}
& \phi_{5}=-2,296 \phi_{3}+\left(3,296-0,03148 \omega^{2}\right) \phi_{4} \\
& \phi_{6}=-1,086 \phi_{4}+\left(2,086-0,02581 \omega^{2}\right) \phi_{5} \\
& \phi_{7}=-1,101 \phi_{5}+\left(2,101-0,02379 \omega^{2}\right) \phi_{6} \\
& \phi_{8}=-2,395 \phi_{6}+\left(3,395-0,04591 \omega^{2}\right) \phi_{7} \\
& \phi_{9}=-0,400 \phi_{7}+\left(1,400-0,01392 \omega^{2}\right) \phi_{8} \\
& \phi_{10}=-0,736 \phi_{8}+\left(1,736-0,00807 \omega^{2}\right) \phi_{9} \\
& \phi_{11}=-3,931 \phi_{9}+\left(4,931-0,02359 \omega^{2}\right) \phi_{10}
\end{aligned}
$$$$
\phi_{53}=6,031
$$$$
\phi_{63}=5,701
$$$$
\phi_{73}=3,921
$$$$
\phi_{83}=-2,219
$$$$
\phi_{93}=-4,351
$$$$
\phi_{103}=-5,553
$$

$\phi_{113}=-8,911$

\section{Analisis respon spektrum}

\section{Penentuan kelas situs lokasi penelitian}

Contoh perhitungan dalam menentukan kelas situs lokasi penelitian menggunakan titik pengujian BH01. Analisis penentuan kelas situs berdasarkan titik pengujian $\mathrm{BH} 01$ dapat dilihat pada Tabel 10. Kelas situs untuk area yang diwakili oleh titik pengujian BH01 dapat ditentukan menggunakan persamaan (BSN, 2012):

$$
\bar{N}=\frac{\sum_{i=1}^{n} d_{i}}{\sum_{i=1}^{n} \frac{d_{i}}{N_{i}}}=\frac{16}{0,601}=26,627
$$

Tabel 10 Hasil analisis kelas situs BH01

\begin{tabular}{cccc}
\hline $\begin{array}{c}\text { Kedalaman } \\
(\mathrm{m})\end{array}$ & $\begin{array}{c}\text { Tebal, } d \\
(\mathrm{~m})\end{array}$ & $N$ & $d / N$ \\
\hline 1 & 1 & 10 & 0,100 \\
3 & 2 & 11 & 0,182 \\
4 & 1 & 13 & 0,077 \\
5 & 1 & 17 & 0,058 \\
6 & 1 & 60 & 0,017 \\
7 & 1 & 60 & 0,017 \\
8 & 1 & 60 & 0,017 \\
10 & 2 & 60 & 0,033 \\
12 & 2 & 60 & 0,033 \\
14 & 2 & 60 & 0,033 \\
16 & 2 & 60 & 0,033 \\
\hline \multicolumn{5}{c}{ Total } & & 0,601 \\
\hline
\end{tabular}

Berdasarkan hasil perhitungan, dapat diketahui bahwa area yang diwakili oleh titik pengujian BH01 termasuk ke dalam kelas situs tanah sedang $(S D)$. Hasil rekapitulasi menunjukkan bahwa seluruh area underpass termasuk dalam kelas situs yang sama sehingga nilai percepatan muka tanah maksimum $\left(a_{\max }\right)$ sama pada seluruh lokasi (Tabel 11).
Tabel 11 Rekapitulasi kelas situs

\begin{tabular}{ccc}
\hline Titik bor & $\bar{N}$ & Kelas situs \\
\hline BH01 & 26,627 & $S D$ \\
BH02 & 34,476 & $S D$ \\
BH03 & 32,773 & $S D$ \\
BH04 & 39,446 & $S D$ \\
BH05 & 27,719 & $S D$ \\
\hline
\end{tabular}

\section{Penentuan percepatan gempa}

Mengacu peta gerak tanah seismik kemungkinan $2 \%$ terlampaui dalam 50 tahun $\left({ }^{M C E_{R}} 2 \%\right.$ dalam 50 tahun) pada SNI 17262012, diperoleh nilai parameter $S_{S}$ dan $S_{l}$ masing-masing berurutan $0,90 \mathrm{~g}$ dan $0,40 \mathrm{~g}$.

\section{Penentuan parameter spektrum respons} Nilai $F_{a}$ dan $F_{v}$ ditentukan berdasarkan SNI 1726-2012. Dengan melakukan interpolasi linier, diperoleh nilai $F_{a}$ dan $F_{v}$ berturut-turut 1,14 dan 1,60. Setelah diketahui nilai faktor amplifikasi seismik periode pendek $\left({ }^{F_{a}}\right)$ dan periode $1 \operatorname{detik}\left({ }^{F_{v}}\right)$, maka nilai parameter respons spektral dapat ditentukan sebagai berikut :

$S_{M S}=F_{a} S_{S}=1,14 \times 0,90=1,03 \mathrm{~g}$

$S_{M l}=F_{v} S_{l}=1,60 \times 0,40=0,64 \mathrm{~g}$

\section{Penentuan spektrum respon desain}

Pada pembuatan kurva spektrum respon desain, terlebih dahulu harus ditentukan nilai parameter percepatan spektral desain untuk periode pendek, $S_{D S}$ dan periode 1 detik, $S_{D I}$. Penentuan nilai $S_{D S}$ dan $S_{D I}$ dengan menggunakan persamaan sebagai berikut:

$$
\begin{aligned}
& S_{D S}=\frac{2}{3} S_{M S}=\frac{2}{3} \times 1,03=0,68 \mathrm{~g} \\
& S_{D I}=\frac{2}{3} S_{M I}=\frac{2}{3} \times 0,64=0,43 \mathrm{~g}
\end{aligned}
$$


Tahapan selanjutnya menentukan besaran periode getar $T_{0}$ dan $T_{S}$ dengan menggunakan persamaan sebagai berikut:

$T_{0}=0,2 \frac{S_{D 1}}{S_{D S}}=0,2 \times \frac{0,43}{0,68}=0,13 \mathrm{dt}$

$T_{S}=\frac{S_{D 1}}{S_{D S}}=\frac{0,43}{0,68}=0,63 \mathrm{dt}$

Setiap lapisan tanah pada lokasi titik BH01 mempunyai nilai redaman tanah yang berbeda-beda, dan diperoleh nilai redaman rerata, $\bar{D}=26,13 \%$. Maka nilai redaman rerata diambil sebesar, $\bar{D}=26 \%$ (pembulatan). Nilai koreksi percepatan spektral dengan redaman 5\% menjadi redaman 26\%, dilakukan perhitungan menggunakan persamaan sebagai berikut (NZSEE, 2006):

$$
\begin{aligned}
S_{D S}(26 \%) & =C_{26 \%}=C_{5 \%}\left(\frac{7}{2+\lambda_{\text {ieff }}}\right)^{0,5} \\
& =0,68 \times\left(\frac{7}{2+26}\right)^{0,5}=0,34 \mathrm{~g} \\
S_{D 1}(26 \%) & =C_{26 \%}=C_{5 \%}\left(\frac{7}{2+\lambda_{\text {ieff }}}\right)^{0,5} \\
& =0,43 \times\left(\frac{7}{2+26}\right)^{0,5}=0,22 \mathrm{~g}
\end{aligned}
$$

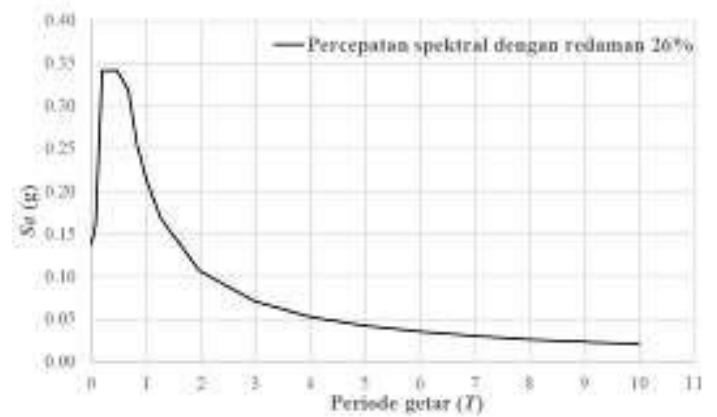

Gambar 9 Spektral percepatan dengan redaman $26 \%$

Gambar 9 menunjukkan hasil plot spektral percepatan dengan redaman 26\% dengan mengambil rentang waktu antara 0 sampai 10 detik. Sedangkan Tabel 12 menunjukkan nilai spektral percepatan $\left(S_{a}\right)$ pada titik pengujian $\mathrm{BH} 01$ yang diperoleh dari nilai periode getar alami. Cara yang sama diterapkan pada seluruh titik pengujian.
Tabel 12 Nilai spektral percepatan $\left(S_{a}\right)$ titik BH01

\begin{tabular}{ccc}
\hline \multirow{2}{*}{$T$} & \multicolumn{2}{c}{$S_{a}$} \\
\cline { 2 - 3 } & $(\mathrm{g})$ & $\left(\mathrm{m} / \mathrm{s}^{2}\right)$ \\
\hline 1 & 0,02 & 0,23 \\
2 & 0,07 & 0,68 \\
3 & 0,11 & 1,07 \\
4 & 0,17 & 1,65 \\
5 & 0,25 & 2,51 \\
6 & 0,32 & 3,13 \\
7 & 0,34 & 3,35 \\
8 & 0,34 & 3,35 \\
9 & 0,34 & 3,35 \\
10 & 0,34 & 3,35 \\
11 & 0,16 & 1,59 \\
\hline
\end{tabular}

\section{Analisis spektrum respons struktur $M D O F$}

Pada metode spektrum respon, respon struktur dihitung berdasarkan pada spektrum respon untuk daerah gempa tertentu. Nilai simpangan dapat dihitung. Namun, sebelum menghitung nilai simpangan maka terlebih dahulu dihitung massa total pada tiap mode shape dengan mengacu kepada persamaan berikut:

1) Mode shape 1

$$
M_{i}^{*}=\{\phi\}_{i}^{T}[M]\{\phi\}_{i}=25977 \mathrm{ton} / \mathrm{m}^{2}
$$

$L_{i}^{*}=\{\phi\}_{i}^{T}[M]\{r\}=901,53 \mathrm{ton} / \mathrm{m}^{2}$

2) Mode shape 2

$$
\begin{aligned}
& M_{i}^{*}=\{\phi\}_{i}^{T}[M]\{\phi\}_{i}=5757,603 \mathrm{ton} / \mathrm{m}^{2} \\
& L_{i}^{*}=\{\phi\}_{i}^{T}[M]\{r\}=520,43 \mathrm{ton} / \mathrm{m}^{2}
\end{aligned}
$$

Kemudian nilai simpangan maksimum, $\{u\}_{i-\max }$ setiap lapisan tanah dapat ditentukan.

- Simpangan mode shape 1

$$
\{u\}_{i-\max }=\{\phi\}_{1} \frac{L_{1}^{*}}{M_{1}^{*}} \frac{1}{\omega_{1}^{2}} S_{a 1}=\left(\begin{array}{l}
0,017 \\
0,035 \\
0,072 \\
0,114 \\
0,208 \\
0,307 \\
0,412 \\
0,657 \\
0,750 \\
0,816 \\
1,066
\end{array}\right)
$$


Tabel 13 Nilai simpangan struktur tanah titik pengujian BH01

\begin{tabular}{ccccccccccccc}
\hline Massa & $u_{1}$ & $u_{2}$ & $u_{3}$ & $u_{4}$ & $u_{5}$ & $u_{6}$ & $u_{7}$ & $u_{8}$ & $u_{9}$ & $u_{10}$ & $u_{11}$ & Simpangan \\
\hline 1 & 0.02 & 0.01 & 0.02 & 0.01 & 0.00 & 0.00 & 0.00 & 0.00 & 0.00 & 0.00 & 0.00 & 0.02 \\
2 & 0.03 & 0.03 & 0.03 & 0.02 & 0.01 & 0.00 & 0.00 & 0.00 & 0.00 & 0.00 & 0.00 & 0.03 \\
3 & 0.07 & 0.06 & 0.06 & 0.02 & 0.00 & 0.00 & 0.00 & 0.00 & 0.00 & 0.00 & 0.00 & 0.07 \\
4 & 0.11 & 0.09 & 0.08 & 0.02 & 0.00 & 0.00 & 0.00 & 0.00 & 0.00 & 0.00 & 0.00 & 0.11 \\
5 & 0.21 & 0.14 & 0.10 & 0.00 & -0.01 & 0.00 & 0.00 & 0.00 & 0.00 & 0.00 & 0.00 & 0.21 \\
6 & 0.31 & 0.19 & 0.10 & -0.02 & -0.01 & 0.01 & 0.00 & 0.00 & 0.00 & 0.00 & 0.00 & 0.31 \\
7 & 0.41 & 0.22 & 0.07 & -0.04 & 0.01 & 0.00 & 0.00 & 0.00 & 0.00 & 0.00 & 0.00 & 0.41 \\
8 & 0.66 & 0.24 & -0.04 & -0.03 & 0.02 & -0.01 & 0.00 & 0.00 & 0.00 & 0.00 & 0.00 & 0.66 \\
9 & 0.75 & 0.24 & -0.07 & -0.02 & 0.01 & 0.00 & 0.00 & 0.00 & 0.00 & 0.00 & 0.00 & 0.75 \\
10 & 0.82 & 0.23 & -0.09 & 0.00 & 0.00 & 0.01 & 0.00 & 0.00 & 0.00 & 0.00 & 0.00 & 0.82 \\
11 & 1.07 & 0.17 & -0.15 & 0.05 & -0.06 & 0.03 & 0.00 & 0.00 & 0.00 & 0.00 & 0.00 & 1.07 \\
\hline
\end{tabular}

Tabel 14 Nilai simpangan struktur tanah titik pengujian BH02

\begin{tabular}{ccccccccccccc}
\hline Massa & $u_{1}$ & $u_{2}$ & $u_{3}$ & $u_{4}$ & $u_{5}$ & $u_{6}$ & $u_{7}$ & $u_{8}$ & $u_{9}$ & $u_{10}$ & $u_{11}$ & Simpangan \\
\hline 1 & 0.02 & 0.01 & 0.02 & 0.01 & 0.01 & 0.01 & 0.00 & 0.00 & 0.00 & 0.00 & 0.00 & 0.02 \\
2 & 0.03 & 0.03 & 0.03 & 0.02 & 0.01 & 0.01 & 0.00 & 0.00 & 0.00 & 0.00 & 0.00 & 0.03 \\
3 & 0.07 & 0.05 & 0.06 & 0.03 & 0.01 & 0.00 & 0.00 & 0.00 & 0.00 & 0.00 & 0.00 & 0.07 \\
4 & 0.10 & 0.08 & 0.07 & 0.03 & 0.00 & -0.01 & 0.00 & 0.00 & 0.00 & 0.00 & 0.00 & 0.10 \\
5 & 0.19 & 0.13 & 0.09 & 0.01 & -0.02 & -0.01 & 0.00 & 0.00 & 0.00 & 0.00 & 0.00 & 0.19 \\
6 & 0.31 & 0.19 & 0.08 & -0.02 & -0.02 & 0.02 & 0.00 & 0.00 & 0.00 & 0.00 & 0.00 & 0.31 \\
7 & 0.46 & 0.23 & 0.04 & -0.04 & 0.01 & 0.00 & 0.00 & 0.00 & 0.00 & 0.00 & 0.00 & 0.46 \\
8 & 0.62 & 0.25 & -0.02 & -0.04 & 0.03 & -0.02 & 0.00 & 0.00 & 0.00 & 0.00 & 0.00 & 0.62 \\
9 & 0.79 & 0.24 & -0.09 & -0.01 & 0.01 & 0.01 & 0.00 & 0.00 & 0.00 & 0.00 & 0.00 & 0.79 \\
10 & 0.84 & 0.23 & -0.10 & 0.00 & 0.00 & 0.01 & 0.00 & 0.00 & 0.00 & 0.00 & 0.00 & 0.84 \\
11 & 1.06 & 0.16 & -0.13 & 0.04 & -0.04 & 0.00 & 0.00 & 0.01 & 0.00 & 0.00 & 0.00 & 1.06 \\
\hline
\end{tabular}

Tabel 15 Nilai simpangan struktur tanah titik pengujian BH03

\begin{tabular}{ccccccccccccc}
\hline Massa & $u_{1}$ & $u_{2}$ & $u_{3}$ & $u_{4}$ & $u_{5}$ & $u_{6}$ & $u_{7}$ & $u_{8}$ & $u_{9}$ & $u_{10}$ & $u_{11}$ & Simpangan \\
\hline 1 & 0.01 & 0.01 & 0.01 & 0.01 & 0.01 & 0.00 & 0.00 & 0.00 & 0.00 & 0.00 & 0.00 & 0.01 \\
2 & 0.03 & 0.03 & 0.03 & 0.01 & 0.01 & 0.01 & 0.00 & 0.00 & 0.00 & 0.00 & 0.00 & 0.03 \\
3 & 0.07 & 0.06 & 0.05 & 0.02 & 0.01 & 0.00 & 0.00 & 0.00 & 0.00 & 0.00 & 0.00 & 0.07 \\
4 & 0.11 & 0.09 & 0.07 & 0.02 & 0.00 & -0.01 & 0.00 & 0.00 & 0.00 & 0.00 & 0.00 & 0.11 \\
5 & 0.19 & 0.13 & 0.08 & 0.01 & -0.02 & 0.00 & 0.00 & 0.00 & 0.00 & 0.00 & 0.00 & 0.19 \\
6 & 0.32 & 0.19 & 0.06 & -0.02 & -0.01 & 0.01 & 0.00 & 0.00 & 0.00 & 0.00 & 0.00 & 0.32 \\
7 & 0.47 & 0.22 & 0.02 & -0.04 & 0.02 & -0.01 & 0.00 & 0.00 & 0.00 & 0.00 & 0.00 & 0.47 \\
8 & 0.67 & 0.23 & -0.05 & -0.02 & 0.01 & -0.01 & 0.00 & 0.00 & 0.00 & 0.00 & 0.00 & 0.67 \\
9 & 0.76 & 0.22 & -0.08 & -0.01 & 0.00 & 0.00 & 0.00 & 0.00 & 0.00 & 0.00 & 0.00 & 0.76 \\
10 & 0.81 & 0.20 & -0.08 & 0.00 & -0.01 & 0.01 & 0.00 & 0.00 & 0.00 & 0.00 & 0.00 & 0.81 \\
11 & 0.99 & 0.13 & -0.09 & 0.04 & -0.03 & 0.02 & 0.00 & 0.00 & 0.00 & 0.00 & 0.00 & 0.99 \\
\hline
\end{tabular}

Tabel 16 Nilai simpangan struktur tanah titik pengujian BH04

\begin{tabular}{ccccccccccc}
\hline Massa & $u_{1}$ & $u_{2}$ & $u_{3}$ & $u_{4}$ & $u_{5}$ & $u_{6}$ & $u_{7}$ & $u_{8}$ & $u_{9}$ & Simpangan \\
\hline 1 & 0.02 & 0.02 & 0.02 & 0.00 & 0.00 & 0.00 & 0.00 & 0.00 & 0.00 & 0.02 \\
2 & 0.05 & 0.05 & 0.03 & 0.01 & 0.00 & 0.00 & 0.00 & 0.00 & 0.00 & 0.05 \\
3 & 0.10 & 0.08 & 0.05 & 0.00 & 0.00 & 0.00 & 0.00 & 0.00 & 0.00 & 0.10 \\
4 & 0.15 & 0.11 & 0.05 & 0.00 & 0.00 & 0.00 & 0.00 & 0.00 & 0.00 & 0.15 \\
5 & 0.28 & 0.14 & 0.02 & -0.02 & 0.00 & 0.00 & 0.00 & 0.00 & 0.00 & 0.28 \\
6 & 0.39 & 0.14 & -0.02 & -0.01 & 0.00 & 0.00 & 0.00 & 0.00 & 0.00 & 0.39 \\
7 & 0.44 & 0.13 & -0.04 & 0.00 & 0.00 & 0.00 & 0.00 & 0.00 & 0.00 & 0.44
\end{tabular}


Vol. 4 No.1 Januari 2021

http://jurnal.umsb.ac.id/index.php/RANGTEKNIKJOURNAL

Rang Teknik Journal

\begin{tabular}{ccccccccccc}
8 & 0.51 & 0.09 & -0.05 & 0.01 & 0.00 & 0.00 & 0.00 & 0.00 & 0.00 & 0.51 \\
9 & 0.69 & -0.01 & -0.07 & 0.03 & 0.01 & 0.00 & 0.00 & 0.00 & 0.00 & 0.69 \\
\hline
\end{tabular}

Tabel 17 Nilai simpangan struktur tanah titik pengujian BH05

\begin{tabular}{ccccccccccccc}
\hline Massa & $u_{1}$ & $u_{2}$ & $u_{3}$ & $u_{4}$ & $u_{5}$ & $u_{6}$ & $u_{7}$ & $u_{8}$ & $u_{9}$ & $u_{10}$ & $u_{11}$ & Simpangan \\
\hline 1 & 0.01 & 0.01 & 0.01 & 0.01 & 0.00 & 0.00 & 0.00 & 0.00 & 0.00 & 0.00 & 0.00 & 0.01 \\
2 & 0.04 & 0.04 & 0.03 & 0.02 & 0.01 & 0.00 & 0.00 & 0.00 & 0.00 & 0.00 & 0.00 & 0.04 \\
3 & 0.07 & 0.06 & 0.04 & 0.02 & 0.01 & 0.00 & 0.00 & 0.00 & 0.00 & 0.00 & 0.00 & 0.07 \\
4 & 0.11 & 0.08 & 0.05 & 0.02 & 0.00 & 0.00 & 0.00 & 0.00 & 0.00 & 0.00 & 0.00 & 0.11 \\
5 & 0.19 & 0.13 & 0.06 & 0.01 & -0.02 & -0.01 & 0.00 & 0.00 & 0.00 & 0.00 & 0.00 & 0.19 \\
6 & 0.30 & 0.19 & 0.05 & -0.02 & -0.02 & 0.01 & 0.00 & 0.00 & 0.00 & 0.00 & 0.00 & 0.30 \\
7 & 0.42 & 0.23 & 0.02 & -0.04 & -0.01 & 0.01 & 0.00 & 0.00 & 0.00 & 0.00 & 0.00 & 0.42 \\
8 & 0.65 & 0.28 & -0.04 & -0.04 & 0.04 & -0.02 & 0.00 & 0.00 & 0.00 & 0.00 & 0.00 & 0.65 \\
9 & 0.90 & 0.30 & -0.10 & -0.01 & 0.03 & 0.01 & 0.00 & 0.00 & 0.00 & 0.00 & 0.00 & 0.90 \\
10 & 0.96 & 0.30 & -0.10 & -0.01 & 0.02 & 0.01 & 0.00 & 0.00 & 0.00 & 0.00 & 0.00 & 0.96 \\
11 & 1.15 & 0.26 & -0.10 & 0.03 & -0.04 & -0.01 & 0.00 & 0.00 & 0.00 & 0.00 & 0.00 & 1.15 \\
\hline
\end{tabular}

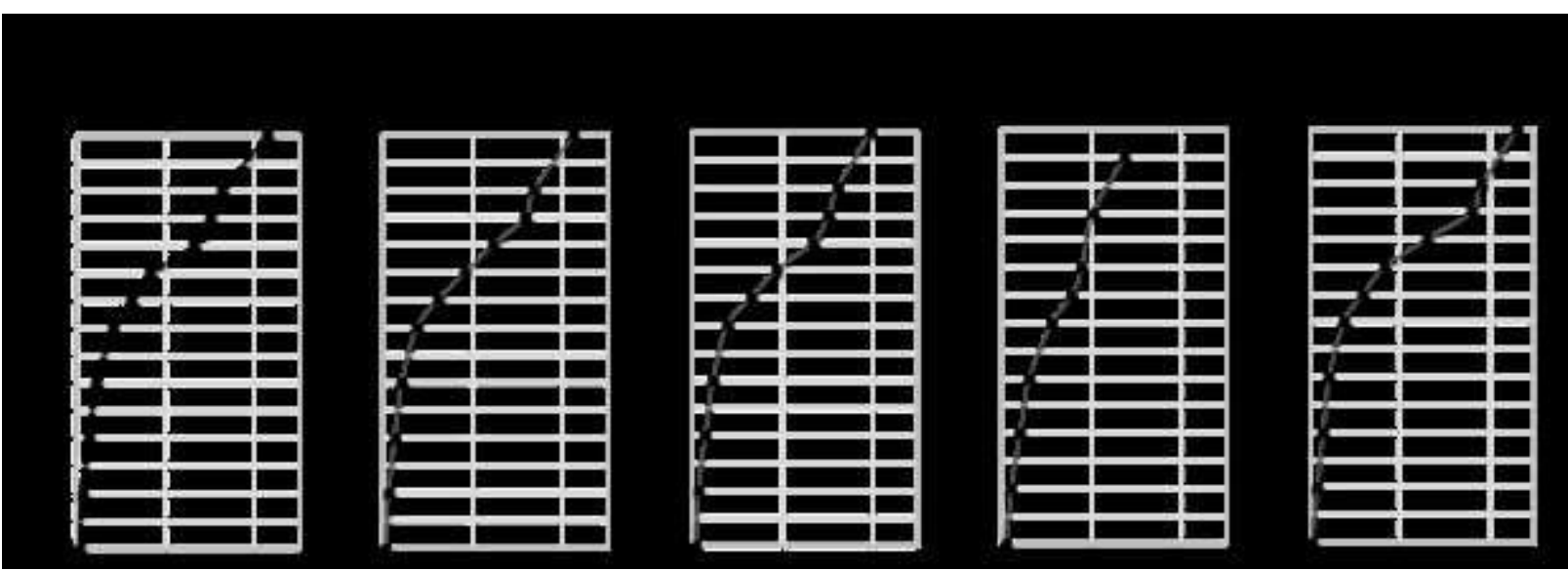

Gambar 10 Grafik simpangan maksimum pada seluruh titik pengujian kawasan Underpass YIA

Hasil perhitungan simpangan setiap mode shape pada titik pengujian $\mathrm{BH} 01$ ditunjukkan pada Tabel 13. Kemudian diambil nilai simpangan maksimum $\left(u_{\text {maks }}\right)$ dari setiap lapisan tanah. Pada Tabel 13 tampak bahwa simpangan mode ke-1 atau lower mode adalah dominan dan simpangan mode ke-11 atau higher mode adalah minor. Nilai simpangan pada titik pengujian BH02 - BH05 diperoleh dengan cara yang sama. Adapun hasil analisis simpangan maksimum $\left(u_{\text {maks }}\right)$ pada titik pengujian $\mathrm{BH} 02$ - BH05 ditunjukkan pada Tabel 14 - Tabel 17.

Gambar 10 menunjukkan grafik simpangan maksimum di lokasi seluruh titik pengujian. Tidak terdapat perbedaan nilai simpangan yang signifikan diantara 5 titik pengujian. Nilai simpangan terbesar berada pada lokasi titik pengujian BH05 sebesar $1,15 \mathrm{~m}$. sedangkan nilai simpangan terkecil sebesar $0,01 \mathrm{~m}$ berada di lokasi titik pengujian BH03 dan BH05.
Semakin mendekati permukaan tanah, nilai simpangan semakin membesar. Hal ini dikarenakan nilai kekakuan tanah $(k)$ dan massa tanah $(m)$ semakin mendekati permukaan semakin kecil. Selain itu, nilai periode getar $(T)$ yang berpengaruh terhadap nilai percepatan spektral $\left(S_{a}\right)$ pada respon spektrum semakin mendekati permukaan tanah semakin mengecil.

\section{SIMPULAN}

Lapisan tanah pada kawasan Underpass YIA tergolong jenis tanah sedang (SD) berdasarkan kategori kelas situs SNI 1726-2012.

Potensi likuifaksi pada 5 titik pengujian di lokasi Underpass YIA terjadi pada kedalaman 4-6 $\mathrm{m}$ dari permukaan tanah jika terjadi gempa bumi dengan nilai $a_{\max }$ lebih besar dari 0,44 g.

Berdasarkan respon spektrum dengan redaman $26 \%$, besaran percepatan spektral 
desain $\left(S_{a}\right)$ untuk titik pengujian BH01 berkisar antara $0,02 \mathrm{~g}-0,34 \mathrm{~g}$ atau $0,23 \mathrm{~m} / \mathrm{s}^{2}-$ $3,35 \mathrm{~m} / \mathrm{s}^{2}$

Berdasarkan analisis respon dinamik tanah struktur $M D O F$ dan model shear building, besaran respon seismik berupa simpangan/lendutan setiap lapisan tanah pada seluruh titik pengujian di kawasan Underpass YIA berkisar antara $0,01 \mathrm{~m}-1,15 \mathrm{~m}$.

\section{UCAPAN TERIMA KASIH}

Ucapan terima kasih disampaikan kepada Kementerian Pekerjaan Umum dan Perumahan Rakyat Republik Indonesia, serta Unit Satuan Kerja Pelaksanaan Jalan Nasional Provinsi Daerah Istimewa Yogyakarta Direktorat Jenderal Bina Marga Kementerian Pekerjaan Umum dan Perumahan Rakyat atas dukungannya dalam pelaksanaan penelitian ini.

\section{REFERENSI}

Bowles, J. E. (1984). Sifat-Sifat Fisis dan Geoteknis Tanah: Mekanika Tanah (Edisi 2). Jakarta: Erlangga.

BSN. (2012). SNI 1726:2012 tentang tata cara perencanaan ketahanan gempa untuk struktur bangunan gedung dan non gedung. Jakarta: Badan Standarisasi Nasional.

Das, B. M. (1993). Mekanika Tanah. Surabaya.

Hardin, B.O, \& Richart, F. . (1963). Elastic Wave Velocities in Granular Soils. Journals of the Soil Mechanics and Foundations Division, 89, 33-65.

Hardin, Bobby O., \& Drnevich, V. P. (1972). Shear Modulus and Damping in Soils: Design Equations and Curves. Geotechnical Special Publication, (118 II), 1459-1484.

Idriss, I. ., \& Seed, H. B. (1968). Seismic Response of Horizontal Soil Layers. Journal of the Soil Mechanics and Foundations Division, 94(4), 1003-1034.

Jalil, A., Fathani, T. F., Satyarno, I., \& Wilopo, W. (2020). A Study on The Liquefaction Potential in Banda Aceh City After the 2004 Sumatera Earthquake. International Journal of GEOMATE, 18(65), 147-155. https://doi.org/10.21660/2020.65.94557

Kristian, Y. (2013). Analisis Respon Dinamik Tanah yang Berpotensi Likuifaksi di
Kawasan Kabupaten Bantul. Universitas Gadjah Mada.

NZSEE. (2006). NZSEE 2006. Assessment and Improvement of the Structural Performance of Buildings in Earthquakes. Recommendations of a NZSEE Study Group on Earthquake Risk Buildings. Diambil dari http://www.nzsee.org.nz/db/PUBS/2006 AISBEGUIDELINES_Corr_06a.pdf

Pawirodikromo, W. (2017). Analisis Dinamik Struktur (Cetakan I). Yogyakarta: Pustaka Pelajar.

Peta Geologi Lembar Yogyakarta Jawa. (1977).

Pusat Studi Gempa Nasional (Indonesia). (2017). Peta sumber dan bahaya gempa Indonesia tahun 2017 (Cetakan Pertama). Bandung: Balitbang Kementerian PUPR.

Rahman, M. A. (2019). Laporan Magang Pembangunan Underpass New Yogyakarta International Airport (NYIA). Yogyakarta.

Seed, B. H. B., Asce, F., Wong, R. T., Asce, M., Idriss, I. M., Asce, M., \& Tokimatsu, K. (1986). Moduli and Damping Factors for Dynamic Analyses of Cohesionless Soils. Journal of Geotechnical and Geoenvironmental Engineering, 112(11), 1016-1032.

Suhendro, B. (2000). Analisis Dinamik Struktur. Yogyakarta: Jurusan Teknik Sipil dan Lingkungan Universitas Gadjah Mada. 